Jap. J. M. Sc. \& Biol., 10, 149-155, 1957

\title{
STUDIES ON THE PROTEIN OF VARIOUS MYCOBACTERIA \\ III. ON THE CHEMICAL PROPERTIES OF THE SEVERAL PEPTIDES ISOLATED FROM THE BACTERIAL CELLS \\ OF MYCOBACTERIUM AVIUM
}

TAICHI SOMEYA ${ }^{1)}$

Laboratory of Tuberculosis of the 2nd Tokyo National Hospital, Tokyo2)

(Received: February 26th, 1957)

In a successive series of papers published from our laboratory by Kasuya et al. (1956) and Hirai (1956), extensive studies on the chemical properties of the proteins obtained both from the culture filtrate and from the bacterial cells of the human tubercle bacilli have been reported.

The technique of the investigation used throughout these works has been the same in principle; namely, that every protein should be separated into its single peptides, and their identification and classification should in turn define the chemical characteristics of the original protein as a starting material.

With respect to the methodology, it can be said that such an approach is considered to play an important role also in exploring chemical knowledge on the protein of the different species of Mycobacteria. Thus, in major part, this paper deals with an application of the same methods to the study of the constituting peptide of Myco. avium. However, as a minor difference, it is to be mentioned that only the protein extracted from dried and defatted bacterial cells by dilute sulfuric acid was used as a starting material because the yield of protein from the culture filtrate was, generally, very small. Also, as to the technique of the determination of the N-terminal residue, not only the DNPtechnique but also the PTC-(phenylthiocarbamyl) method were utilized when necessary.

\section{Materials AND Methods}

Starting Material: Myco. avium-62 was cultured for six weeks in Lockemann's synthetic medium. Cells which were filtered from the unheated culture by filter paper were dried and defatted. From these defatted cells, the protein was extracted in quite the same way as was described by Hirai (1956).

1)染谷太乙, Research fellow in the Medical Department of the 2nd Tokyo National

Hospital (Laboratory Director: ISAKU KASUYA, M.D.)

2) 国立東京第二病院結核研究室 
Homogeneity Test: This was done by Tiselius Electrophoresis (Fig. 1).

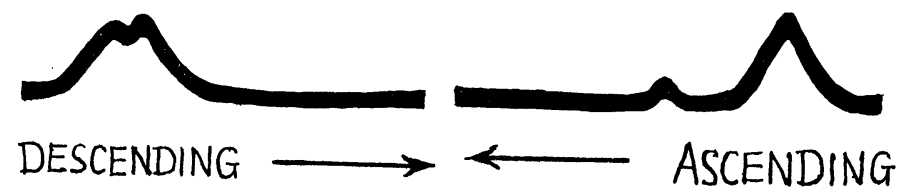

Fig. 1. Tiselius electrophoretic patterns of Sa. (Sadako Hirai, 1956) prepared from the culture filtrate of Myco. avium-62, in phosphate buffer $\mathrm{pH} 7.8,65 \mathrm{~V}$., $8 \mathrm{~mA} ., 45 \mathrm{~min}$.

Isolation of the DNP- and PTC-Peptide by the Counter Current Distribution $(C C D)$ : The technique used in the preparation of the DNP-protein, its partial degradation and the separation of the resultant DNP-peptides were quite the same as were described in a previous paper (Kasuya et al., 1956).

However, as will be discussed later, the failure of the DNP-method in identifying the N-terminal residue of the peptide contained in the fast moving peak (e) has necessitated the introduction of the PTC-method in combination with the CCD. The PTC-derivative of protein was prepared by the method of E. O. P. Thompson (1954). One hundred $\mathrm{mg}$ of protein previously oxidized with performic acid was dissolved in $3 \mathrm{cc}$ of dioxane- $\mathrm{H}_{2} \mathrm{O}=1: 1(\mathrm{v} / \mathrm{v})$, to which was then added $0.2 \mathrm{cc}$ of phenyl-isothiocyanate under stirring. The $\mathrm{pH}$ had been adjusted to 8.6 throughout the reaction. After stirring for 40 minutes the reaction was completed, and the solvent was evaporated in reduced pressure, and the PTC-peptide thus obtained was subjected to CCD by the same solvent system as was used in the separation of DNP-peptides. In the case of PTC-peptide, the color was more faintly brownish, so the approximate site of the peak was detected by the measurement of optical density at $500 \mu \mathrm{m}$.

The Identification of the DNP- and PTC-Peptides: The methods of the identification of the DNP-peptides which were separated by CCD was the same as described previously (Kasuya et al., 1956). But the stepwise degradation of the PTC-peptide was carried out according to the method described by S. W. Fox (1951); that is, Peak (e) was drawn out, and after complete removal of the solvent in vacuo, it was! incubated at $37^{\circ} \mathrm{C}$ for 6 hours with the addition of $3 \mathrm{cc}$ of dioxane preliminarily saturated with dry hydrogen chloride gas at room temperature. Then the dioxane- $\mathrm{HCl}$ was evaporated in reduced pressure, and the residue was distributed between benzene$\mathrm{H}_{2} \mathrm{O}$ (1:1) with shaking. For the regeneration of the amino acid of thiohydantoin, the benzene phase, containing thiohydantoin of the $\mathrm{N}$-terminal residue, was dried and hydrolyzed in a sealed tube at $120^{\circ} \mathrm{C}$ for 24 hours with a mixture of formic acid: acetic acid anhydride: perchloric acid 1.0:5.5:1.5 (v/v), after W. S. Reith et al. (1954).

The tube was then cut very carefully as it contained a high pressure of oxygen which was evolved during the hydrolysis. The acid was neutralized by $\mathrm{N}-\mathrm{KOH}$ to $\mathrm{pH} 3.0$ against BPB. After removal of the major part of the solvent in reduced pressure, it was left for 24 hours in a vacuum desiccator over sulfuric acid and sodium hydroxide. Then the regenerated amino acid was extracted with ethanol: $\mathrm{H}_{2} \mathrm{O}=1: 1$, and was run in paper chromatography. For the development of the color not only $0.2 \%$ ninhydrin in butanol was used but also $0.2 \%$ isatin in acetone containing $4 \%$ acetic acid was employed (Oreskes et al., 1955).

The molar ratio of the yielded peptides designated in terms of the area under the curve measured by paper method (Kasuya et al., 1956). 


\section{RESULT}

1. CCD patterns of the DNP-peptides are shown in Figs. 2 to 5. The molar ratio of the peptides yielded in each peak is as follows:

$$
\mathrm{a}: \mathrm{d}: \mathrm{e}=315: 443: 720=(\operatorname{circ} a) 1: 1: 2
$$

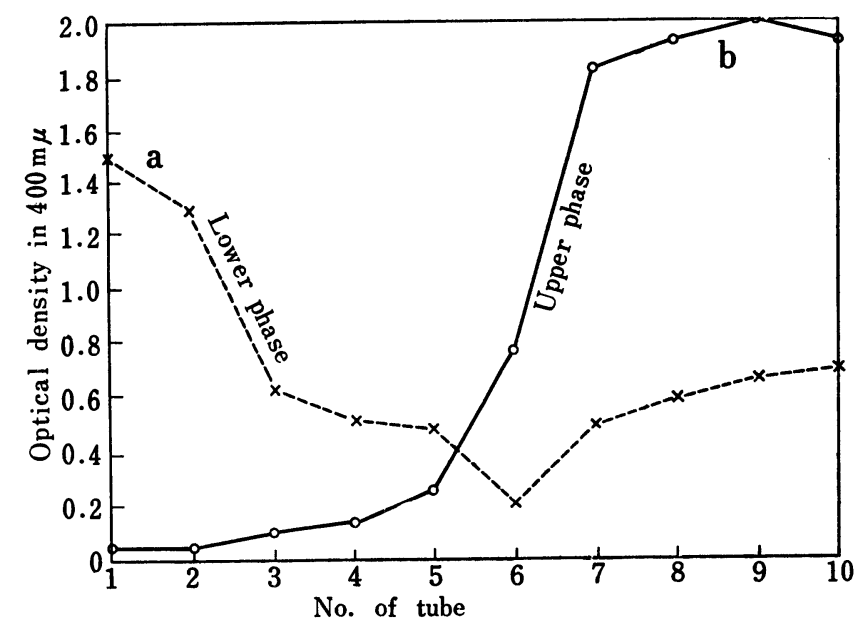

Fig. 2. CCD-i, CCD $\left(\frac{\mathrm{n}-\mathrm{BuOH}}{5 \%-\mathrm{NH}_{4} \mathrm{OH}}\right)$ of DNP-Sa. Myco. avium-62 affer $\mathrm{H} \cdot \mathrm{COOOH}$ treatment.

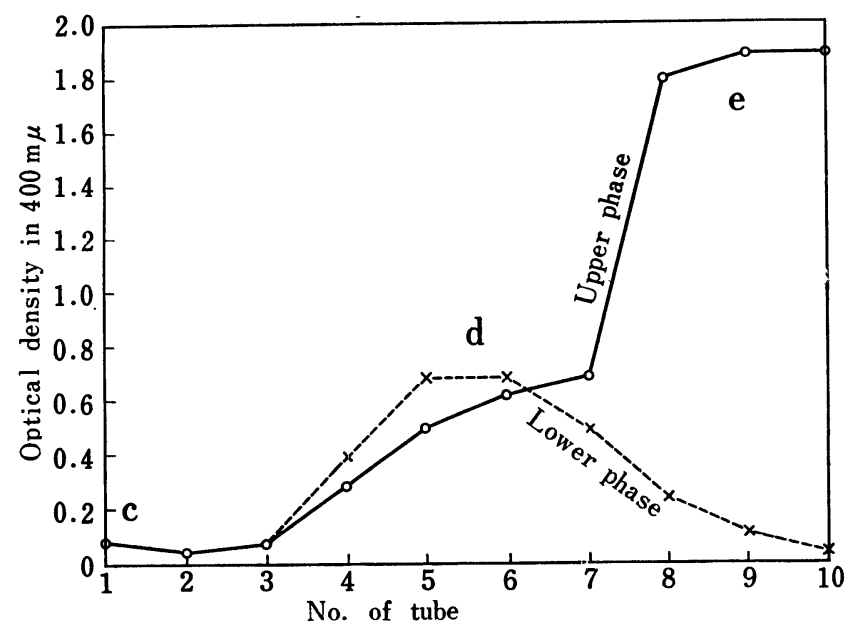

Fig. 3. CCD-ii, CCD $\left(\frac{\text { AcOEt }}{\text { pH6.8-Phosph. buff. }}\right)$ of the peak $b$ in Fig. 2. 


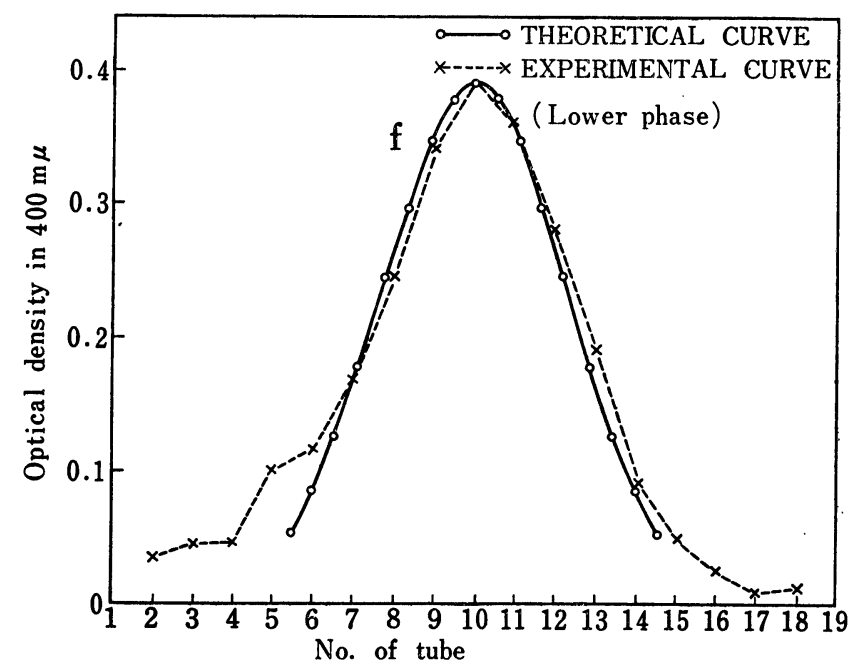

Fig. 4. CCD-iii, Re-CCD $\left(\frac{\text { AcOEt }}{\mathrm{pH} 6.8-\text { Phosph. buff. }}\right)$ of the peak d in Fig 3.

a) DNP-Derivatives

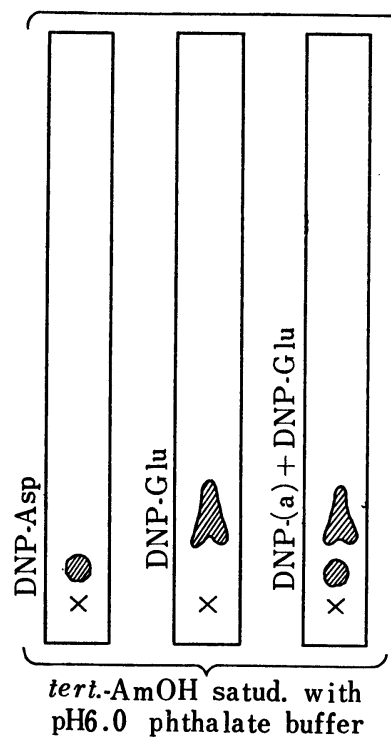

b) Amino Acids Regenerated

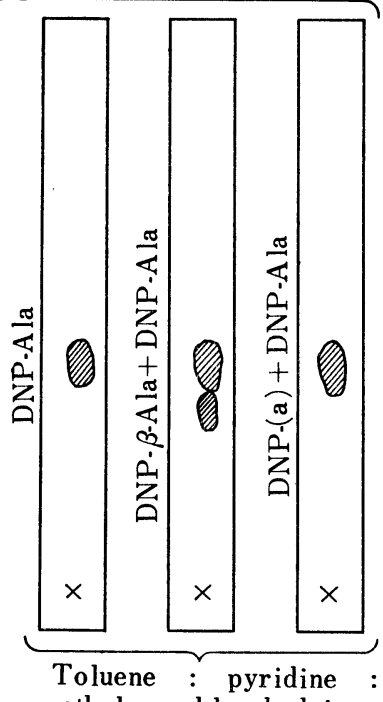

ethylene chlorohydrine : $0.8 \mathrm{~N}^{-\mathrm{NH}_{4}} \mathrm{OH}=5: 1: 3: 3$ from PTC-Derivative

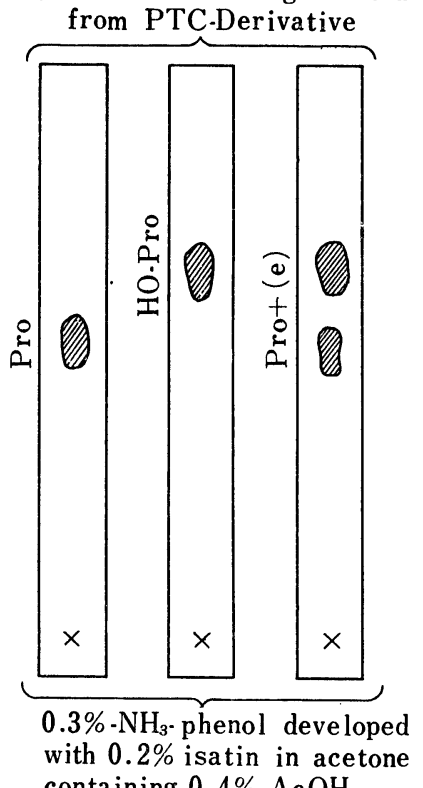
containing $0.4 \% \mathrm{AcOH}$

Fig. 5. Paper-chromatogram of the N-terminal amino acids

2. Paper chromatograph of the DNP-amino acids, and of the amino acids regenerated from the PTC-derivatives, as the N-terminal residues. The results are summarized in Table 1 , 
Table 1. Catalogue of the constituting peptide isolated from DNP-peptide by CCD after preliminary oxidation with performic acid

\begin{tabular}{|c|c|c|c|c|}
\hline $\begin{array}{l}\text { Obtained } \\
\text { from } \\
\text { peak }\end{array}$ & $\begin{array}{l}\text { N-terminal } \\
\text { residue }\end{array}$ & $\mathbf{K}$ & Amino acid composition & $\begin{array}{l}\text { Peptide } \\
\text { No. }\end{array}$ \\
\hline a & DNP-Asp & 0.1 & $\begin{array}{l}\text { Asp-[Ser. Gly. } \mathrm{MetSO}_{2 .} \text { Try. Thr. Val.- } \\
\left.\alpha-\mathrm{NH}_{2} \text {-Bu. Glu. CySO }{ }_{3} \mathrm{H}\right]\end{array}$ & I \\
\hline$d$ & DNP-Ala & 1.0 & $\begin{array}{l}\text { Ala-[Asp. Glu. } \alpha, \varepsilon-\left(\mathrm{NH}_{2}\right)_{2}-\mathrm{Pim} \text {. Tau. Gly.- } \\
\left.\text { Tyr. Leu. Lys. Arg. } \mathrm{CySO}_{3} \mathrm{H}\right]\end{array}$ & II \\
\hline $\mathrm{e}$ & HO-Pro & 1.8 & HO-Pro-[Glu. Ala. His. Val. Tyr. $\left.\mathrm{CySO}_{3} \mathrm{H}\right]$ & III \\
\hline
\end{tabular}

\section{Discussion}

First to be discussed is the method of identification of the N-terminal residue of the peptide contained in Peak (e). Here the DNP-method had failed to yield any DNP-amino acid except dinitroaniline, probably because of the destruction either of the imino ring of proline or of the imidazol ring of histidine, when they were the $\mathrm{N}$-terminal residue in question. In this case, the use of the PTC method, however, gave a satisfactory result in proving the residue to be hydroxyproline: the color developed by ninhydrin was yellowish brown, by isatin blue green (Oreskes et al., 1955); and its $\mathrm{Rf}$ value was 0.51 in $0.3 \%$ $\mathrm{NH}_{3}$-phenol which is more characteristic of hydroxyproline than of proline.

Next to be discussed is the significance of the results with respect to the chemical differences in the proteins of the different species of mycobacteria. The immunological difference, observed by skin test, between the tuberculin protein of Myco. avium and that of the mammalian type of tubercle bacilli, viz. Myco. tbc. var. humanus and bovinus, has been shown already by F. B. Seibert and Morley (1950). But from the chemical viewpoint, no appreciable contribution has appeared except the data of the overall amino acid analysis of the avian tubercle bacilli by Yamamura and Shimizu (1950). Now, according to our results, the chemical difference of the proteins obtained from the bacterial cells of the two different species of Mycobacterium, viz. Myco. avium and Myco. tbc. var. humanus has been clearly demonstrated.

The peptide obtained from Peak (a) was:

Asp-\{Ser.Gly.MetSO 2 Try.Thr.Val. $\alpha-\mathrm{NH}_{2}$ Bu.Glu.CySO $\left.{ }_{3} \mathrm{H}\right\}$

the aspartic acid peptide, which was quite similar to the one previously obtained from the human tubercle bacilli (Kasuya et al., 1956), and so far said to be the species common.

Nevertheless, from Peak (d) :

Ala-[Asp.Glu. $\alpha, \varepsilon-\left(\mathrm{NH}_{2}\right)_{2}$ Pim.Tau.Gly.Tyr.Leu.Lys.Arg.CySO $\left.{ }_{3} \mathrm{H}\right\rceil$

alanine peptide has been obtained; while in contrast to this, the peptide obtained from the corresponding peak of the human tubercle bacilli is, as is already known, 
$\beta$-Ala peptide (Kasuya and Hagitani, 1955; Kasuya et al., 1956). And it is interesting enough that the $\mathrm{N}$-terminal residues of the similar peptides appositive in patition coefficient of the two species of Mycobacteria, pathogenic and non pathogenic, have been proven to be the structural isomers of the alanine reciprocally.

The fact that the $\mathrm{N}$-terminal residue of the peptide from (e) has been proved to be a hydroxyproline was an unexpected evidence:

$$
\text { HO-Pro-[Glu.Ala.His.Val.Tyr.CySO } \left.{ }_{3} \mathrm{H}\right\rceil \ldots \ldots \text { (III) }
$$

This is also interesting when we consider the peptide from the corresponding peak in the case of the human tubercle bacilli was also $\beta$-Ala peptide. This reminds us too of the fact that the only instance in which proline has been found to be the $\mathrm{N}$-terminal residue of a peptide was the case in protamin (Ando te al., 1952).

The original protein was shown to have single peak in electophoretical curve visualized under the condition given in Fig. 1. However, in reference to the numbers of the variety of the peptides obtained, and the molar ratio mentioned in the experimental part, the original protein is also considered to be a mixture of at least two components as was in the case of the previous report (Kasuya et al., 1956), which is supposed to be as follows:

$$
\begin{aligned}
& \text { Component } \mathrm{A}^{3)}=\text { Peptide (I) +Peptide (III) } \\
& \text { Component } \mathrm{B}^{3)}=\text { Peptide (II) +Peptide (III) }
\end{aligned}
$$

\section{SUMMARY}

1. The constituting peptides of the protein obtained by dilute sulfuric acid extraction from dried and defatted bacterial cells of Myco. avium, have been studied.

2. The techniques used in this investigation were in major part the same as those used in the previous papers except that, for the identification of $\mathrm{N}$-terminal residue, not only the DNP-technique was employed, but also the PTC (phenyl-thiocarbamyl) method was also introduced, by which the identification of the N-terminal residue of the hydroxy-proline-peptide was made possible.

3. As a result, the constituting peptides have been proved to be each one mol of aspartic acid peptide, and alanine peptide, and two mols of hydroxy-proline peptide.

4. The comparative biochemical difference of the constituting peptides of Myco. avium and of Myco. tbc. var. humanus has been discussed.

In conclusion author indebt his sincere thanks to the Prof. Emeritus C. Nishino, the director of the hospital for his permission, and also to Dr. I. Kasuya of the laboratory for his guidance in performing this research work.

3) A and B are the two components of proteins supposed to have approximately the same mobility in electrophoresis, 


\section{REFERENCES}

Ando, T., Ishii, S., Hashimoto, C., Yamazaki, K. and Iwai, K. (1952) : On the constituent amino acids, $\mathrm{N}$-terminal residues, and the molecular weights of protamin. Bull. Chem. Soc. Japan, 25, 132.

Fox. S. W., Hurst, T. L. and Itscher, K. E. (1951): A microbiological method for the determination of sequence of amino acid residues. J. Am. Chem. Soc., 73, 35733575.

Hirai, S. (1956) : Studies on the proteins of various mycobacteria II. On the chemical properties of the several peptides isolated from the tuberculin protein obtained from the bacterial cells of human strain Aoyama-B and Frankfurt. Jap. J. M. Sc. \& Biol., 9, 179-189.

Kasuya, I., Goto, J., Hirai, S., Someya, T. and Hagitani, A. (1956): Studies on the proteins of various mycobacteria I. On the chemical properties of the several peptide isolated from the oxidized tuberculin protein obtained from the culture filtrate of the human strain Aoyama-B. Jap. J. M. Sc. \& Biol., 9, 93-102.

Oreskes, I. and Saifer, A. (1955) : Qualitative determination of amino acids in protein hydrolysate by circular paper-chromatography. Anal. Chem., 27, 854-856.

Reith, W. S. and Waldron, N. M. (1954): Studies on the determinations of the sequence of amino acids in peptide and proteins. Biochem. J. 56, 116-120.

Seibert, F. B. and Morley, N. (1950): The relationship of the tuberculin proteins of different acid-fast bacilli to sensitization as indicated by their reactivity in sensitized animals. Am. Rev. Tuberc., 61, 149-156.

Thompson, E.O.P. (1954): The N-terminal sequence of serum albumin. Observation on the thiohydantoin method. J. Biol. Chem., 208, 565-572.

Yamamura, Y. and Shimizu, Y. (1950): On the analysis of amino acids of the tubercle bacilli and tuberculin by paper-chromatography. "Iryo", 4, 13-14 (text in Japanese). 